Influence of fish meal reduction, algae addition, and ... (Sebastian Kaspers)

\title{
INFLUENCE OF FISH MEAL REDUCTION, ALGAE ADDITION, AND ENZYME USE IN SHRIMP FEEDSON THE TISSUE COMPOSITION OF Litopenaeus vannamei
}

\author{
Sebastian Kaspers" and Andreas Kunzmann \\ Leibniz-Center for Tropical Marine Ecology, Fahrenheitstr. 6, 28359 Bremen, Germany
}

(Received 10 October 2011 ; Accepted 17 March 2012)

\begin{abstract}
At the Leibniz-Center for Tropical Marine Ecology in Bremen, Germany, shrimps (Litopenaeus vannamei) fed feeds with reduced fish meal content, algae and enzyme additions were analysed for their tissue composition. Contents of protein, glycogen, total lipid, linoleic acid (LA), alpha linolenic acid (ALA), eicosapentaenoic acid (EPA) and docosahexaenoic acid (DHA) of the shrimp abdomen and of the respective feeds were determined. Reduction of fish meal (FM) content in shrimp feed and its substitution with "mash" (grain distillery waste- "Schlempe"), corn gluten, pea or coarse colza meal did not influence the tissue composition. Additional inclusion of an algae mixture out of Spirulina spp., Phaeodactylum spp., and Tetraselmis spp. to shrimp feeds as well as the single inclusions of Phaeodactylum spp. or Spirulina spp. had no effect on the tissue composition. Furthermore no improvement of the quality of the shrimps due to an enhanced digestibility of mash by enzymes (mixture of corolase, phytase, xylanase) could be detected. In contrast the quality of shrimps seemed to be negatively affected by enzymes in this study. These findings could contribute to making shrimp aqua farming more economic as reduction of feed costs without reduction of the quality of the shrimps would be a large benefit.
\end{abstract}

\section{KEYWORDS: shrimp, tissue composition, fatty acid composition, feed addition, fish meal, microalgae}

\section{INTRODUCTION}

In order to improve feed management and reduce costs, several studies were done on the feed and nutrient requirements of fish and shrimp (Akiyama, 1992; Bureau et al., 2000; Lupatsch et al., 2008) and on the substitution of fish meal and fish oil (Amaya et al., 2007a+b; Davis \& Arnold, 2000; Davis et al., 2004; Samocha et al., 2004; Smith et al., 2000; Suárez et al., 2009). A summary of studies about fish meal replacement in shrimp feeds is also given in Fox et al. (2004).
One problem occurring with the substitution of fish proteins with plant proteins in aquaculture feeds is the low digestibility of plant proteins compared with those of marine origin. Although Akiyama et al. (1989) showed that apparent protein digestibility was not influenced by animal or plant feedstuff origin, Fenucci et al. (1982) observed differences in protein assimilation according to its source (animal or vegetable). To solve this problem, enzymes like amylase were effectively supplemented to shrimp diets to increase their di-

\# Corresponding author. Leibniz- Center for Tropical Marine Ecology, Fahrenheitstr. 6, 28359 Bremen, Germany Sebastian Kaspers, Burscheider Str. 129, 51381 Leverkusen, Phone: +4917696141218

E-mail address: sebastian.kaspers@googlemail.com ; akunzmann@zmt-bremen.de 
gestibility and shrimp growth (Maugle et al., 1983). Also Buchanan et al. (1997) stated an improved weight gain for Penaeus monodon through the addition of exogenous enzymes to a diet with canola meal. In contrast Divakaran $\&$ Velasco (1999) could not detect any positive or negative effects of enzyme addition to shrimp feed on the growth performance of the shrimp.

Another problem arising with the substitution of fish meal and fish oil in aquaculture feeds is the resulting lack of essential fatty acids (EFA) in the diets. EFAs are generally delivered from high- quality marine lipids which account for $50-100 \mathrm{~g} \mathrm{~kg}-1$ in commercial production feeds (Davis, 2005) and which are important in shrimp nutrition (Akiyama, 1992). The National Research Council (1993) depicted the fatty acid composition of common animal fats, fishand vegetable oils. It is shown, that fish oil contains high amounts of the essential fatty acids EPA and DHA, which "are essential for normal growth and survival of marine penaeid shrimp" (Fox et al., 2004), whereas animal fats (e.g. poultry fat) and vegetable oils (e.g. soybean oil), which are used as substitutes for fish meal and fish oil, are missing these EFAs. In order to compensate deficits in EFAs in aquaculture feeds and to cover the EFA requirements of the target organisms, marine algae rich in EFAs are added to the diets (Benemann, 1992; Duerr et al., 1998; Gladue \& Maxey, 1994; Ju et al., 2009; Spolaore et al., 2006).

Sriket et al. (2007) pointed out the important role which seafood plays in human diet and that black tiger shrimp and white shrimp contain high amounts of protein and polyunsaturated fatty acids (dominantly DHA and EPA) and therefore are a good source of these nutrients. It is further stated that "the compositions can vary with feed" and that "Differences in proximate composition might result in differences in nutritional value [...] of the shrimps."

EPA and DHA are important omega- 3 fatty acids with positive effects on many health disorders (Liebke, 2007). LA and ALA are the parent compounds of the omega- 6 and omega- 3 fatty acids and the omega- 6: omega- 3 ratio is also important for human health (Simopoulos et al., 1999). Today this ratio is 15-30:1 due to high levels of omega- 6- fatty acids in our foods (for example in sunflower oil; Rüsing, 2007). For a healthy diet a ratio of 5:1 is recommended as seen in the reference values for nutrient intake (German Nutrition Society (DEG) et al., 2002).

The present study focuses on the concern, that alterations in feed compositions could affect the tissue composition of shrimps and therewith might change their nutritional value for human consumption. The Hypothesis to be tested is that the addition of mash, corn gluten, pea or coarse colza meal to shrimp feed, as well as the addition of micro algae or digestibility enhancing enzymes has an effect on the tissue composition of Litopenaeus vannamei. To investigate if the tissue composition changes due to the specific treatments, the protein, carbohydrate and total lipid content as well as the content of LA, ALA, EPA, and DHA in shrimp abdomen has been determined.

\section{MATERIALS AND METHODS}

In this study, carried out at the LeibnizCenter for Tropical Marine Ecology in Bremen, Germany, samples of frozen shrimps (Litopenaeus vannamei) and feeds out of several feeding experiments (Table 1) were analysed for their nutrient composition. The feeding experiments covered the topics fishmeal substitutes, qualification of microalgae as feed addition and the qualification of mash as feed addition under the influence of enzymes. As fishmeal substitutes mash, corn gluten, pea and coarse colza meal were included in a commercial shrimp feed up to $150 \mathrm{~g} \mathrm{~kg}-1$ respectively. Thereby fishmeal was reduced up to $487,200,226$, and $539 \mathrm{~g}$ $\mathrm{kg}-1$ respectively. In order to investigate the suitability of microalgae as feed addition, a mixture out of Spirulina spp., Phaeodactylum spp. and Tetraselmis spp. was included to shrimp feed up to 5, 10, and $30 \mathrm{~g} \mathrm{~kg}$ - 1 . Also either Phaeodactylum spp. or Spirulina spp. was included to the feed to $10 \mathrm{~g} \mathrm{~kg}$ - 1 . For the investigation of mash as feed addition under the influence of enzymes, enzymes (mixture of corolase, phytase, xylanase) and mash were included in the shrimp feed up to $17 \mathrm{~g} \mathrm{~kg}-1$ and $200 \mathrm{~g} \mathrm{~kg}-1$ respectively.

All post larvae shrimps were fed a commercial reference feed before changing to the test feeds, which were fed over 6- 8 weeks. The experimental feed was the only source of food, cannibalism did not occur, neither did natural productivity because the water was treated 
Influence of fish meal reduction, algae addition, and ... (Sebastian Kaspers)

Table 1. Overview about feeding experiments, tested feeds and dry weight of the respective shrimp abdomen, $\mathrm{FM}=$ fish meal

\begin{tabular}{|c|c|c|c|}
\hline Experiment & Feed & Replicate & $\begin{array}{l}\text { Dry weight of } \\
\text { abdomen [g] }\end{array}$ \\
\hline $\begin{array}{l}\text { Initial } \\
\text { situation }\end{array}$ & $\begin{array}{l}\text { Commercial reference - start } \\
\text { (no FM substitutes) }\end{array}$ & $\begin{array}{l}1 \\
2 \\
3 \\
4 \\
5 \\
6\end{array}$ & $\begin{array}{l}1.0574 \\
1.8730 \\
2.2667 \\
0.5441 \\
0.5869 \\
0.3572\end{array}$ \\
\hline $\begin{array}{l}\text { Fish meal } \\
\text { substitutes }\end{array}$ & $\begin{array}{l}\text { Commercial reference } \\
\text { (no FM substitutes) } \\
\text { Mash addition } \\
\text { (150 g kg-1) } \\
\text { Corn gluten addition } \\
\text { (150 g kg-1) } \\
\text { Pea addition } \\
\text { (150 g kg- } 1 \text { ) } \\
\text { Coarse colza meal addition } \\
\text { (150 g kg-1) }\end{array}$ & $\begin{array}{l}1 \\
2 \\
3 \\
4 \\
1 \\
2 \\
3 \\
1 \\
2 \\
3 \\
1 \\
2 \\
3 \\
1 \\
2 \\
3\end{array}$ & $\begin{array}{c}\text { Not available } \\
0.9313 \\
1.8394 \\
2.5559 \\
1.3837 \\
1.2405 \\
1.4471 \\
1.7657 \\
1.6269 \\
1.4312 \\
1.0406 \\
1.2193 \\
1.3805 \\
1.3961 \\
1.4806 \\
1.3735\end{array}$ \\
\hline $\begin{array}{l}\text { Microalgae } \\
\text { addition }\end{array}$ & $\begin{array}{l}\text { Reference } \\
\text { (no algae) } \\
\text { Algae mix addition } \\
\text { (5 g kg-1) } \\
\text { Algae mix addition } \\
\text { (10 g kg-1) } \\
\text { Algae mix addition } \\
\text { (30 g kg-1) } \\
\text { Phaeodactylum spp. addition } \\
\text { (10 g kg-1) } \\
\text { Spirulina spp. addition } \\
\text { (10 g kg- } 1 \text { ) }\end{array}$ & $\begin{array}{l}1 \\
2 \\
3 \\
1 \\
2 \\
3 \\
1 \\
2 \\
3 \\
1 \\
2 \\
3 \\
1 \\
2 \\
3 \\
1 \\
2 \\
3\end{array}$ & $\begin{array}{l}1.1053 \\
0.7129 \\
0.8021 \\
0.8257 \\
0.7609 \\
1.0990 \\
0.6714 \\
1.0731 \\
0.7775 \\
0.6812 \\
0.5120 \\
0.8574 \\
1.0763 \\
1.0430 \\
0.8159 \\
0.7907 \\
0.8689 \\
1.0470\end{array}$ \\
\hline $\begin{array}{l}\text { Mash and enzyme } \\
\text { addition }\end{array}$ & $\begin{array}{l}\text { No mash, } \\
\text { Enzyme addition (17 g kg-1) } \\
\text { Mash addition (200 g kg-1), } \\
\text { Enzyme addition (17 g kg-1) }\end{array}$ & $\begin{array}{l}1 \\
2 \\
3 \\
1 \\
2 \\
3\end{array}$ & $\begin{array}{l}0.6120 \\
0.6779 \\
0.6481 \\
0.6501 \\
0.5170 \\
0.5706\end{array}$ \\
\hline
\end{tabular}


several times. All tests were performed indoor in a closed recirculation system under the conditions stated in Table 2.

In order to eliminate experimental variables other than feed composition that could affect body composition e.g. developmental stage as well as stress due to starvation, temperature, salinity or light, these variables were maintained constant. Thus only shrimps with an equal start weight were used within each of the three experiments (Table 3 ), water parameters were monitored (Table 2 ) and automatic feeding devices were used for an even distribution of the feeding ratios over a day. At the end of the experiments shrimp were sacrificed by plunging them into iced water and stored at $-40^{\circ} \mathrm{C}$ until being analyzed.

From the samples, the isolated and deveined abdomen of shrimps and the respective feeds were freeze- dried and homogenised before they were analysed for their protein- , carbohydrate- and total lipid content as well as for their contents of linoleic acid (LA, 18:2 $(n-6)$ ), alpha linolenic acid (ALA, 18:3(n-3)), eicosapentaenoic acid (EPA, 20:5(n-3)) and docosahexaenoic acid (DHA, 22:6(n- 3)).

The protein content of the samples was detected in a carbon/ nitrogen (C/N) - analysis as described by Ehrenberger (1991). For this, the elemental analyser NA 2100 from Thermo and the standard SRM 1515 (apple leafs) was used.

As the main content of carbohydrates in shrimp tissue is glycogen (Murat \& Serfaty, 1974), the glycogen content of the shrimp abdomen was examined. Thus, glucose was first released enzymatically from glycogen using amyloglucosidase from Aspergillus niger as described in Murat \& Serfaty (1974). Afterwards the released glucose together with free glucose in the tissue was determined photometrically using glucose oxidase and peroxidase with ABTS as a chromogenic substrate (Bruss \& Black, 1978).

Table 2. Experimental conditions and growth parameters for reference feeds in feeding experiments with Litopenaeus vannamei (Kunzmann \& Peppler, unpubl. observ.)

\begin{tabular}{|c|c|c|c|}
\hline Experiment & $\begin{array}{l}\text { Microalgae } \\
\text { addition }\end{array}$ & $\begin{array}{c}\text { Mash and } \\
\text { enzyme addition }\end{array}$ & $\begin{array}{c}\text { Fishmeal } \\
\text { substitutes }\end{array}$ \\
\hline Age of shrimp & 4-5 weeks & ca. 8 weeks & ca. 4.5 month \\
\hline Developmental stage & Post larvae & Juvenile & Adult \\
\hline Experimental period [days] & 45 & 46 & 56 \\
\hline Feeding rate $[\mathrm{g} / \mathrm{d}$, pond] & 2.4 & 2.4 & 1.5 \\
\hline Feeding rate $[\mathrm{g} / \mathrm{d}$, animal] & 0.17 & 0.17 & 0.19 \\
\hline Animals/ aquarium & 14 & 14 & 8 \\
\hline Replicates & 5 & 5 & 5 \\
\hline Water temperature $\left[{ }^{\circ} \mathrm{C}\right]$ & $27.2-28$ & $28-29.6$ & $24.1-28.1$ \\
\hline Salinity [g L-1] & $19.9-20.4$ & $19.2-20.3$ & $19.9-20.6$ \\
\hline $\mathrm{pH}$ & $7.96-8.13$ & 7.1-8.12 & $8.28-8.35$ \\
\hline $\mathrm{NH}_{4}-\mathrm{N}[\mathrm{mg} / \mathrm{L}]$ & $0.1-0.2$ & $0.2-0.7$ & $0.06-0.08$ \\
\hline $\mathrm{NO}_{2}-\mathrm{N}[\mathrm{mg} / \mathrm{L}]$ & $0.03-0.05$ & $0.06-0.08$ & $0.02-0.08$ \\
\hline $\mathrm{NO}_{3}-\mathrm{N}[\mathrm{mg} / \mathrm{L}]$ & $144-178$ & 123-155 & $218-230$ \\
\hline Weight (start) [g] & ca.1.5 (1.49) & 2.83-2.94 (2.9) & $14.6-15.1(14.8)$ \\
\hline Weight (end) [g] & $6.33-7.44(7.3)$ & $6.81-9.54(7.7)$ & $15.3-19(16.65)$ \\
\hline Biomass $\left[\mathrm{g} / \mathrm{m}^{2}\right]$ (end) & 359 & 294.1 & 437 \\
\hline Growth (weight (end) - weight (start)) [g] & $4.9-6.2(5.7)$ & $4-6.8(4.8)$ & $0.8-4.4(1.9)$ \\
\hline Daily growth rate $[\mathrm{g} / \mathrm{d}]$ & 0.11 & 0.115 & 0.034 \\
\hline FCR & 1.66 & 1.99 & 7.88 \\
\hline Mortality [\%] & 1.2 & 14 & 7.5 \\
\hline
\end{tabular}


Influence of fish meal reduction, algae addition, and ... (Sebastian Kaspers)

Table 3. Mortality and average weight of shrimps at start and end of the experiments (Kunzmann, unpubl. observ.)

\begin{tabular}{llccc}
\hline \multirow{2}{*}{ Experiment } & \multicolumn{1}{c}{ Feed } & $\begin{array}{c}\text { Start weight } \\
\text { [g] }\end{array}$ & $\begin{array}{c}\text { End weight } \\
\text { [g] }\end{array}$ & $\begin{array}{c}\text { Mortality } \\
\text { [\%] }\end{array}$ \\
\cline { 2 - 5 } Fish meal & Commercial reference & 14.77 & 16.65 & 7.5 \\
substitutes & Mash & 14.97 & 16.22 & 7.5 \\
& Corn gluten & 14.54 & 16.05 & 2.5 \\
& Pea & 14.99 & 15.47 & 12.5 \\
& Coarse colza meal & 14.7 & 16.74 & 12.5 \\
\hline \multirow{4}{*}{ Microalgae } & Reference (without algae) & 1.49 & 7.29 & 1.4 \\
addition & Algae mix (5 g kg-1) & 1.53 & 7.51 & 1.4 \\
& Algae mix (10 g kg-1) & 1.51 & 7.27 & 7.1 \\
& Algae mix (30 g kg-1) & 1.5 & 7.46 & 14.3 \\
& Phaeodactylum spp. & 1.51 & 7.51 & 5.7 \\
\hline Mash + enzyme & Spirulina spp. & 1.55 & 7.5 & 2.9 \\
addition & No mash, enzymes & 2.81 & 7.49 & 25.7 \\
& Mash, enzymes & 2.84 & 6.33 & 12.9 \\
\hline
\end{tabular}

The total lipids of the samples were extracted as described in Hagen (2000) and then measured gravimetrically. The total lipid extracts of the samples were further analysed for their fatty acid composition by gas- liquid chromatography. Prior to the GC analysis the fatty acids were hydrolysed and derivatised to fatty acid methyl esters (FAMEs) for better detection by the flame- ionisation detector (FID) (Kattner \& Fricke, 1986; Peters et al., 2006).

\section{RESULT AND DISCUSSION}

The growth performances of the shrimp from several feed experiments are given in Table 4. There are significant differences in the tissue composition (Table 5) between the shrimps at the start of the experiment (commercial reference-start) and those at the end (commercial reference) due to growth of the shrimps during the experiment (Table 3 ). This confirms findings of Bureau et al. (2000) that

Table 4. Growth performances of shrimps Litopenaeus vannamei (Kunzmann \& Peppler, unpubl. observ.)

\begin{tabular}{llll}
\hline Experiment & \multicolumn{1}{c}{ Feed variant } & $\begin{array}{c}\text { Growth } \\
\text { [g/day/animal] }\end{array}$ & $\begin{array}{c}\text { Significant } \\
\text { differences } \\
\text { between feed } \\
\text { variants }\end{array}$ \\
\hline Fish meal substitutes & Commercial reference & 0.034 & \\
& Mash & $<0.03$ & no \\
& Corn gluten & $<0.03$ & \\
& Pea & $<0.03$ & no \\
\hline Microalgae addition & Coarse colza meal & 0.036 & no \\
\hline Mash + enzyme addition & All feed variants & $0.10-0.14$ & \\
\hline
\end{tabular}



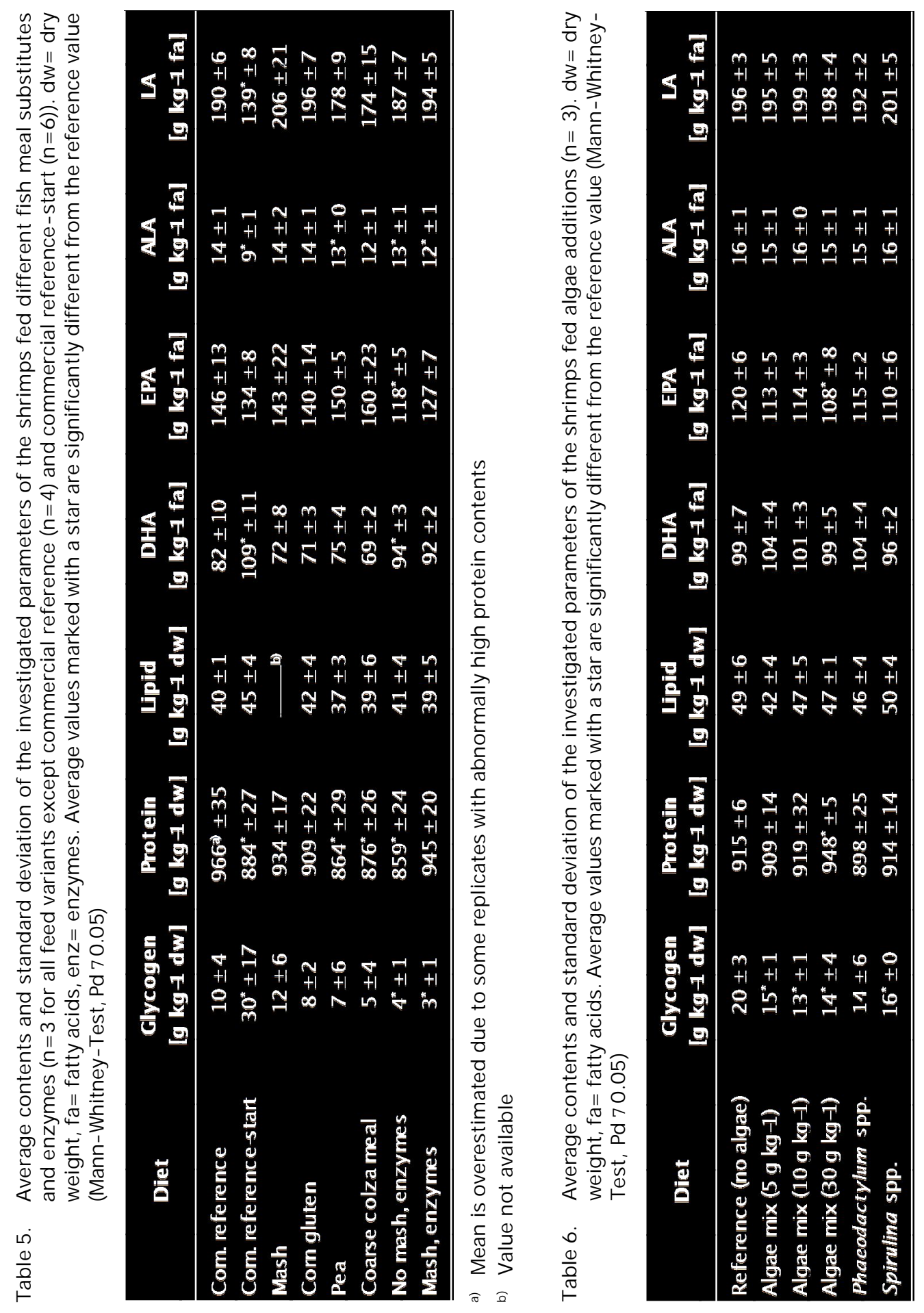
the chemical composition in penaeid shrimps varies with developmental stage. Thus the tissue composition and therewith the nutritional value of shrimps for human consumption differs depending on the developmental stage due to varying deposition of the several nutrients.

\section{Fishmeal Substitutes}

In the tissue composition of the shrimps fed the fishmeal substitutes (Table 5), no significant differences to the shrimps fed the commercial reference were found for the content of glycogen, lipid, DHA, EPA, and LA. Cheng et al. (2002) also stated no significant differences in crude fat content of Juvenile Pacific White Shrimp Litopenaeus vannamei when substituting fish meal by feather meal in shrimp diet.

When replacing fish oil with soy oil Cheng $\&$ Hardy (2004) also found no effect on the composition of LA, ALA, DHA, and EPA in the shrimp body of Litopenaeus vannamei. The difference of $1 \mathrm{~g} \mathrm{~kg}$ - 1 fatty acids in the ALA content between the shrimps fed the pea addition and those fed the commercial reference in the present study is not important in terms of human nutrition. Thus in contrast to expectations no disadvantages for the quality of shrimps could be detected when fed the fishmeal reduced diets. This finding could contribute to making shrimp aqua farming more economic, as reduction of feed costs without reduction of the quality of the shrimps would be a large benefit.

\section{Algae Additions}

Compared to the shrimps fed the reference food without algae additions, no significant differences in the contents of total lipid, DHA, ALA, and LA could be identified in the shrimps fed the algae additions (Table 6). The identified differences in the glycogen, protein and EPA contents between the reference group and the shrimps fed algae additions are very small and therefore negligible in terms of human nutrition. This indicates that the nutritional value of the shrimps for humans can not be improved by adding expensive micro algae to shrimp feeds, as expected.

Also Ju et al. (2009) stated that the fatty acid composition of shrimp tails (Litopenaeus vannamei) was not greatly affected by the addition of either whole algae or algae frac- tions to a formulated diet and that no significant differences were observed in the content of DHA and EPA. However they observed an increased fatty acid content in shrimp tails when adding whole algae to the diet.

\section{Enzyme Additions}

Unlike expected the shrimps fed the enzyme additions did not show improvements in their tissue composition which would be relevant for human nutrition (Table 5). Generally the enzyme addition rather seemed to negatively affect the quality of the shrimps in this study. Divakaran \& Velasco (1999) pointed out that added enzymes could alter the digestive enzyme activities in shrimps which could be an explanation for the negative effect of the added enzymes.

The data also suggest that there is no disadvantage for the quality of the shrimps when feeding mash at an inclusion level of $200 \mathrm{~g} \mathrm{~kg}$ 1 , which would be a benefit for shrimp aqua culture concerning feed costs.

\section{Diets}

Contents of the investigated nutrients in feeds did not alter much, most were within the same range for the single nutrients (Table 7). Observed differences in the contents of the investigated nutrients could be due to the fact that they only represent one single measurement $(n=1)$. Because of the low variation of the composition between the diets, no explicit reflection of the nutrient composition of the feeds could be detected in the shrimp tissue. When changing the amounts of fatty acids in shrimp feeds considerably, González- Félix et al. $(2003 a+b)$ detected a reflection of the fatty acid profile of the feeds in shrimp tissue. Also Lim et al. (1997) and González- Félix et al. (2002) detected a reflection of the fatty acid composition of the test diets in shrimp tissue.

\section{CONCLUSIONS AND OUTLOOK}

The present study focused on concerns, that alterations in compositions of shrimp feed could affect the tissue composition of shrimps and therewith might change their nutritional value for human consumption. The Hypothesis was that the addition of mash, corn gluten, pea or coarse colza meal to shrimp feed, as well as the addition of micro algae or digestibility enhancing enzymes has an effect on the tissue composition of Litopenaeus vannamei. 


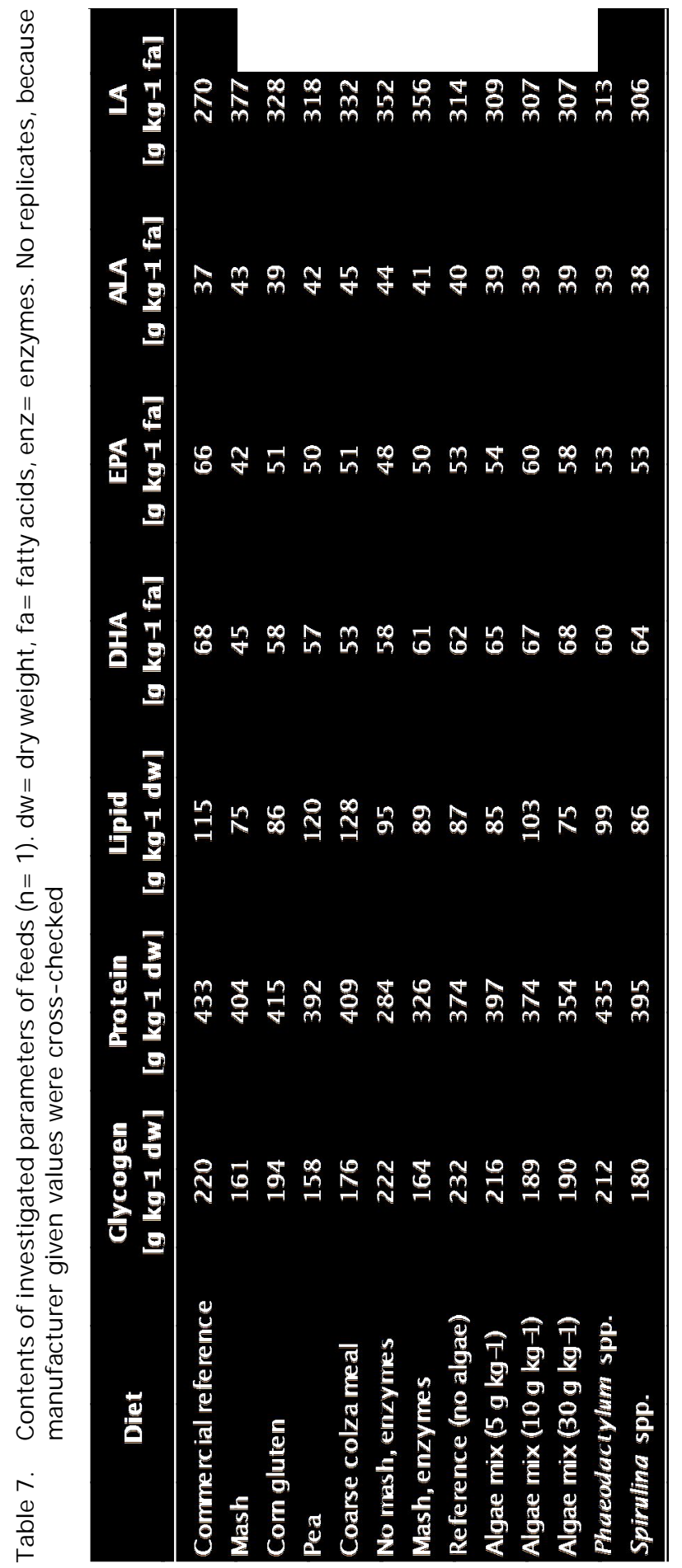


The results of this study showed, that the investigated alterations of the feed composition did not have an influence on the tissue composition of the shrimps and thus did not change their quality in terms of their nutritional value for humans. The investigated algae and enzyme additions were not of immediate benefit for the quality of the shrimps in this study. However, there are many more algae species and enzymes, which might have direct positive effects. Also the effect of algae and enzyme additions on the quality of further shrimp species could be tested. Finally, even if there are no direct benefits for shrimp quality, long term effects on the immune system of the shrimps are highly likely when feeding algae additions, which should be object of a further study. The substitution of fish meal in shrimp feeds by cheaper alternatives like mash, pea, corn gluten or coarse colza meal is promising. It would be interesting to find out whether fish meal can be substituted to even higher amounts without affecting the quality of the shrimps.

\section{ACKNOWLEDGEMENTS}

This publication is part of a MSc thesis at the University of Bremen. The project this work is based on was carried out by the LeibnizCenter for Tropical Marine Ecology in Bremen, Germany in cooperation with Polyplan $\mathrm{GmbH}$ and was financed by the Arbeitsgemeinschaft industrieller Forschungsvereinigungen (AIF). We want to thank Dipl. Ing. Matthias Birkicht and Dr. Sebastian Ferse from the Leibniz- Center for Tropical Marine Ecology, Petra Wencke from the University of Bremen and Tim Heusinger von Waldegge for their contributions and support.

\section{REFERENCES}

Akiyama, D.M., Coelho, S.R., Lawrence, A.L., \& Robinson, E.H. 1989. Apparent Digestibility of Feedstuffs by the Marine Shrimp Penaeus vannamei BOONE. Nippon Suisan Gakkaishi, 55(1): 91- 98.

Akiyama, D.M. 1992. Future considerations for shrimp nutrition and the aquaculture feed industry. In: Proceedings of the Special Session on Shrimp Farming (J. Wyban, editor). World Aquaculture Society, Baton Rouge, LA USA, p. 198- 205.

Amaya, E., Davis, D.A., \& Rouse D.B. 2007a. Alternative diets for the Pacific white shrimp
Litopenaeus vannamei. Aquaculture, 262: 419- 425.

Amaya, E.A., Davis, D.A., \& Rouse D.B. 2007b. Replacement of fish meal in practical diets for the Pacific white shrimp (Litopenaeus vannamei) reared under pond conditions. Aquaculture, 262: 393- 401.

Benemann, J.R. 1992. Microalgae aquaculture feeds. J. Appl. Phycol., 4(3): 233- 245.

Bruss, M.L. \& Black, A.L. 1978. Enzymatic Microdetermination of Glycogen. Anal. Biochem., 84: 309- 312.

Buchanan, J., Sarac H.Z., Poppi, D., \& Cowan, R.T. 1997. Effects of enzyme addition to canola meal in prawn diets. Aquaculture, 151:29- 35.

Bureau, D.P., Azevedo, P.A., Tapia- Salazar, M., $\&$ Cuzon, G. 2000. Pattern and cost of growth and nutrient deposition in fish and shrimp: Potential implications and applications. In: Cruz - Suárez, L.E., Ricque- Marie, D., Tapia- Salazar, M., Olvera- Novoa, M.A. y Civera- Cerecedo, R., (Eds.). Avances en Nutrición Acuícola V. Memorias del V Simposium Internacional de Nutrición Acuícola. 19- 22 Noviembre, 2000. Mérida, Yucatán, Mexico, p. 111- 140.

Cheng, Z.J. \& Hardy R.W. 2004. Protein and lipid sources affect cholesterol concentrations of juvenile Pacific white shrimp, Litopenaeus vannamei (Boone). J. Anim. Sci., 82(4): 1,136- 1,145.

Cheng, Z.J., Behnke K.C., \& Dominy W.G. 2002. Effect of Feather Meal on Growth and Body Composition of the Juvenile Pacific White Shrimp, Litopenaeus vannamei. J. Appl. Aquac., 12(1): 57-69.

Davis, D.A. 2005. Nutrient Requirements of Penaeid Shrimp. Global Aquaculture Advocate, 8(4): 72- 74.

Davis, D.A. \& Arnold, C.R. 2000. Replacement of fish meal in practical diets for the Pacific white shrimp, Litopenaeus vannamei. Aquaculture, 185(3- 4): 291- 298.

Davis, D.A., Samocha, T.M., Bullis, R.A., Patnaik, S., Browdy, C.L., Stokes, A.D., \& Atwood, H.L. 2004. Practical Diets for Litopenaeus vannamei (Boone 1931): Working Towards Organic and/ or All Plant Production Diets. In: Cruz Suárez, L.E., Ricque Marie, D., Nieto López, M.G., Villarreal, D., Scholz, U., y González, M., 2004. Avances en Nutrición Acuícola VII. Memorias del VII Simposium Internacional de Nutrición Acuícola. 16- 19 
Noviembre, 2004. Hermosillo, Sonora, México.

Divakaran, S. \& Velasco M. 1999. Effect of proteolytic enzyme addition to a practical feed on growth of the Pacific white shrimp, Litopenaeus vannamei (Boone). Aquac. Res., 30: 335- 339.

Duerr, E.O., Molnar, A., \&Sato V. 1998. Cultured microalgae as aquaculture feeds. J. Mar. Biotechnol., 7: 65-70.

Ehrenberger, F. 1991. Quantitative organische Elementaranalyse- Analysemethoden zur Bestimmung der Elemente im Makro- , Mikro- und Spurenbereich in organischer und anorganischer Matrix. $\mathrm{VCH}$ Verlagsgesellschaft $\mathrm{mbH}$, Weinheim (Bunderrepublik Deutschland); ISBN: 3- 52728056- 1, p. 202- 215.

Fenucci, J.L., Fenucci, A.C., Lawrence A.L., \& Zein- Eldin, ZP. 1982. THEASSIMILATION OF PROTEIN AND CARBOHYDRATE FROM PREPARED DIETS BY THE SHRIMP, Penaeus stylirostris. J. World Maricul. Soc., 13: 134145.

Fox, J.M., Lawrence, A.L., \& Smith, F. 2004. Development of a Low- fish Meal Feed Formulation for Commercial Production of Litopenaeus vannamei. In: Cruz Suárez, L.E., Ricque Marie, D., Nieto López, M.G., Villarreal, D., Scholz, U., y González, M., 2004. Avances en Nutrición Acuícola VII. Memorias del VII Simposium Internacional de Nutrición Acuícola. 16- 19 Noviembre, 2004. Hermosillo, Sonora, México, p. 238258.

German Nutrition Society (DGE), Austrian Nutrition Society (ÖGE), Swiss Society for Nutrition Research (SGE) \& Swiss Nutrition Association (SVE), $1^{\text {st }}$ edition in German 2000, $1^{\text {st }}$ edition in English 2002. Reference Values for Nutrient Intake. Umschau Braus $\mathrm{GmbH}$, Frankfurt/ Main Germany.

Gladue, R.M. \& Maxey, J.E. 1994. Microalgal feeds for aquaculture. J. Appl. Phycol., 6: 131- 141.

González- Félix, M.L., Lawrence, A.L., Gatlin III, D.M., \& Perez- Velazquez, M. 2002. Growth, survival and fatty acid composition of juvenile Litopenaeus vannamei fed different oils in the presence and absence of phospholipids. Aquaculture, 205: 325- 343.

González- Félix, M.L., Lawrence, A.L., Gatlin III, D.M., \& Perez- Velazquez, M. 2003a Nutritional evaluation of fatty acids for the open thelycum shrimp, Litopenaeus vannamei: I. Effect of dietary linoleic and linolenic acids at different concentrations and ratios on juvenile shrimp growth, survival and fatty acid composition. Aquac. Nutr., 9: 105113.

González- Félix, M.L., Gatlin III, D.M., Lawrence, A.L., \& Perez-Velazquez, M. 2003b. Nutritional evaluation of fatty acids for the open thelycum shrimp, Litopenaeus vannamei: II. Effect of dietary n- 3 and n- 6 polyunsaturated and highly unsaturated fatty acids on juvenile shrimp growth, survival, and fatty acid composition. Aquac. Nutr., 9: 115122.

Hagen, W. 2000. Lipids. In: Harrris R., Wiebe P., Lenz J., Skjoldal H., Huntley M., (eds) ICES zooplankton methodology manual. Academic, San Diego, p. 113- 119.

Ju, Z.Y., Forster, I.P., \& Dominy, W.G. 2009. Effects of supplementing two species of marine algae or their fractions to a formulated diet on growth, survival and composition of shrimp (Litopenaeus vannamei). Aquaculture, 292: 237- 243.

Kattner, G. \& Fricke, H.S.G. 1986. Simple gasliquid chromatographic method for the simultaneous determination of fatty acids and alcohols in wax esters of marine organisms. J. Chroat., 361: 263- 268.

Liebke, F. 2007. Meer Gesundheit! Setzten sie auf die wichtigen Omega- 3- Fettsäuren EPA/DHA. Remerc \& Leihw Verlagskontor.

Lim, C., Ako H., Brown, C.L., \& Hahn, K. 1997. Growth response and fatty acid composition of juvenile Penaeus vannamei fed different sources of dietary lipid. Aquaculture, 151: 143- 153.

Lupatsch, I., Cuthbertson, L., Davies, S., \& Shields, R.J. 2008. Studies on Energy and Protein Requirements to Improve Feed Management of the Pacific White Shrimp, Litopenaeus vannmei. In: Cruz Suárez, L.E., Ricque Marie, D., Tapia Salazar, M., Nieto López, M.G., Villarreal Cavazos, D.A., Lazo, J.P., y Viana, M.T. (Eds). Avances en Nutrición Acuícola IX. IX Simposio Internacional de Nutrición Acuícola. 24- 27 Noviembre. Universidad Autónoma de Nuevo León, Monterrey, Nuevo León, México, p. 281295.

Maugle, P.D., Deshimaru, O., Katayama, T., \& Simpson, K.L. 1983. THE USE OF AMYLASE SUPPLEMENTS I N SHRIMP DIETS. J. World Maricul. Soc., 14: 25- 37. 
Murat, J.C. \& Serfaty, A. 1974. Simple Enzymatic Determination of Polysaccharide (Glycogen) Content of Animal Tissues. Clin. Chem., 20(12): 1,576- 1,577.

National Research Council. 1993. Nutrient requirements of fish. National Academy Press. Washington, D.C. USA 70 p. ISBN: 0309- 04891- 5.

Peters, J., Renz, J., van Beusekom, J., Boersma, M., \& Hagen, W. 2006. Trophodynamics and seasonal cycle of the copepod Pseudocalanus acuspes in the Central Baltic Sea (Bornholm Basin): evidence from lipid composition. Mar. Biol., 149: 1,417- 1,429.

Rüsing, M. 2007 Neuartige Fette-Neue Quellen für Fette und Öle. Schriftenreihe Lebensmittelchemische GesellschaftBand, 28: 55- 65.

Samocha, T.M., Allan Davis, D., Saoud, I.P., \& DeBault, K. 2004. Substitution of fish meal by co- extruded soybean poultry by- product meal in practical diets for the Pacific white shrimp, Litopenaeus vanamei. Aquaculture, 231: 197- 203.

Simopoulos, A. P., Leaf, A., \&Salem, N. Jr. 1999. Workshop on the Essentiality of and Recommended Dietary Intakes for Omega- 6 and Omega- 3 Fatty Acids. J. Am. Coll. Nutr., 18(5): 487- 489.
Smith, D.M., Allan, G.L., Williams, K.C., \& Barlow, C.G. 2000. Fishmeal replacement research for shrimp feed in Australia. In: Cruz Suárez, L.E., Ricque- Marie, D., Tapia- Salazar, M., Olvera- Novoa, M.A., y Civera- Cerecedo, R., (Eds.). Avances en Nutrición Acuícola V. Memorias del V Siposium International de Nutrición Acuícola. 19- 22 Noviembre, 2000. Mérida, Yucatán, México, p. 277- 286.

Spolaore, P., Joannis- Cassan, C., Duran, E., \& Isambert, A. 2006. Commercial Applications of Microalgae. J. Biosci. Bioeng., 101(6): 201211. ISSN: 1389- 1723.

Sriket, P., Benjakul, S., Visessanguan, W., \& Kijroongrojana, K. 2007. Comparative studies on chemical composition and thermal properties of black tiger shrimp (Penaeus monodon) and white shrimp (Penaeus vannamei) meats. Food Chem., 103: 1,199$1,207$.

Suárez, J.A., Gaxiola, G., Mendoza, R., Cadavid, S., Garcia, G., Alanis, G. , Suárez, A., Faillace, J., \& Cuzon, G. 2009. Substitution of fish meal with plant protein sources and energy budget for white shrimp Litopenaeus vannamei (Boone, 1931). Aquaculture, 289(1- 2): 118- 123. 